\title{
SIGNIFIKANSI KEGIATAN EKSTRAKURIKULER KEAGAMAAN DALAM MENCIPTAKAN LINGKUNGAN PENDIDIKAN HUMANIS
}

\author{
I wan
}

\author{
Pendidikan Agama Islam (PAI) FITK IAIN Syekh Nurjati Cirebon \\ Email: aida.queena@gmail.com
}

\begin{abstract}
Abstrak
Kegiatan ekstrakurikuler merupakan kegiatan penunjang intra kurikuler untuk mengembangkan minat dalam menumbuh kembangkan pribadi peserta didik yang sehat jasmani dan rohani, bertaqwa kepada Tuhan Yang Maha Esa, memiliki kepedulian dan bertanggung jawab melalui berbagai kegiatan positif dibawah kewenangan sekolah. Guru dalam konteks pendidikan humanistik diposisikan sebagai fasilitator bagi peserta didiknya. Peran guru dalam proses pembelajaran bukan lagi sebagai orang yang tahu segalanya tanpa melihat keseragaman potensi dan bakat yang sebenarnya dimiliki oleh peserta didik. Metode yang dianggap sesuai dalam penelitian ini adalah dengan menggunakan metode penelitian analisis deskriptif dengan pendekatan kualitatif. Setelah data terkumpul baik data teoritik maupun empirik, selanjutnya adalah menganalisa data. Dalam menganalisis data dipergunakan analisis kualitatif deskriptif.
\end{abstract}

Kata kunci: Ekstra Kurikuler Keagamaan, Lingkungan Pendidikan, Pendidikan Humanis

Extracurricular activities are intra-curricular supporting activities to develop interest in developing personal development of students who are physically and mentally healthy, devoted to the Supreme God, have care and responsibility through various positive activities under the authority of the school. Teachers in the context of humanistic education are positioned as facilitators for their students. The role of the teacher in the learning process is no longer as a person who knows everything without seeing the uniformity of potential and talent actually possessed by students. The method considered appropriate in this study is to use a descriptive analysis research method with a qualitative approach. After 
the data is collected both theoretical and empirical data, then the data is analyzed. In analyzing the data used descriptive qualitative analysis.

Keywords: Religious Curricular Extras, Educational Environment, Humanist Education

\section{A. Pendahuluan}

Pendidikan karakter mengasumsikan keterkaitan erat antara dimensi moral, sosial, ekonomi, politik, hukum, agama, budaya, dan estetika. Pendidikan agama, begitu juga pendidikan kewarganegaraan pada level manapun tidak dapat berbuat banyak jika ia berdiri sendiri (self sufficiency), karena jika tidak dikaitkan dengan budaya, sosial, hukum dan politik misalnya, maka pendidikan agama hanya akan jatuh pada rumus-rumus dan preskripsi-preskripsi normatif, yang mungkin mudah dihapal, tapi seringkali tidak dapat dipraktikkan dan diimplementasikan dalam dunia sosial sehari-hari yang begitu kompleks. Menyadari kesulitan yang begitu kompleks, dengan mengambil inspirasi dari seorang filsuf Jerman era modern, Immanuel Kant, dapat ditegaskan disini bahwa Pendidikan Karakter adalah pendidikan kemanusiaan yang bertujuan menjadikan manusia "baik". Menjadikan manusia "baik" tanpa prasyarat apapun. Meskipun pendapat ini terkesan deontologis dan ahistoris, tapi justru disitulah letak kekuatan dan relevansinya saat ini.

Pada era Negara bangsa (nation states), Pendidikan karakter sangat diperlukan oleh bangsa manapun karena dengan Pendidikan Karakter yang berhasil akan membuat warga masyarakat dan warga negara menjadi "baik" tanpa prasyarat apapun. Menjadikan warga negara yang "baik" tanpa embel-embel syarat agama, sosial, ekonomi, budaya, ras, politik dan hukum. Pendidikan karakter seperti ini sejalan dengan cita-cita kemandirian manusia (moral outonomy) dalam bertetangga, bermasyarakat, berbangsa, dan bernegara. Pendidikan karakter yang sukses akan sama dengan tujuan beragama, bermasyarakat, berbangsa dan bernegara yang baik dalam ranah multikultural, multietnis, multibahasa, multi religi di era globalisasi seperti saat sekarang ini.

Dalam membentuk karakter yang mapan dikalangan siswa, maka bisa ditunjang oleh kegiatan ekstra kurikuler keagamaan yang ada di sekolah. Program ekstrakurikuler secara umum yang diadakan disekolah bertujuan untuk memberikan tambahan pengetahuan, kemandirian, karakter dan keterampilan dikalangan siswa. Secara khusus kegiatan ekstrakurikuler keagamaan akan memberikan pengetahuan dan penanaman nilai spiritual sehingga akan membentuk watak dan moral siswa. 


\section{B. Landasan Teori}

\section{Ekstrakurikuler}

Ekstrakurikuler menurut Kamus Besar Bahasa Indonesia yaitu kegiatan yang berada di luar program yang tertulis didalam kurikulum seperti latihan kepemimpinan dan pembinaan siswa. Kegiatan ekstrakulikuler adalah kegiatan yang dilaksanakan diluar jam sekolah yang telah ditentukan berdasarkan kurikulum yang berlaku. ${ }^{1}$ Kegiatan ini disamping dilaksanakan di sekolah, dapat juga dilaksanakan di luar sekolah guna memperkaya dan memperluas wawasan pengetahuan atau kemampuan meningkatkan nilai atau sikap dalam rangka penerapan pengetahuan dan keterampilan yang telah dipelajari dari berbagai mata pelajaran dan kurikulum sekolah. Kegiatan ini juga dimaksudkan untuk lebih mengkaitkan pengetahuan yang diperoleh dalam program kulikuler dengan keadaan dan kondisi sekitar.

Menurut Suryobroto, kegiatan ekstrakurikuler didefinisikan sebagai kegiatan tambahan di luar struktur program dilaksanakan di luar jam pelajaran biasa agar memperkaya dan memperluas wawasan dan pengetahuan siswa. ${ }^{2}$

2. Pendidikan Humanisme

Istilah humanisme ${ }^{3}$ adalah temuan dari abad ke-19. Dalam bahasa Jerman Humanismus pertama kali diciptakan pada tahun 1808, untuk merujuk pada suatu bentuk pendidikan yang memberikan tempat utama bagi karya-karya klasik Yunani dan Latin. Dalam bahasa Inggris "humanism" mulai muncul agak kemudian. Pemunculan yang pertama dicatat berasal dari tulisan Samuel Coleridge Taylor (1812), di mana kata itu dipergunakan untuk menunjukkan

\footnotetext{
${ }^{1}$ Tim Penyusun Pusat Kamus, Kamus Besar Bahasa Indonesia (Jakarta: Balai Pustaka, Edisi-3, tahun 2007$), 291$.

${ }^{2}$ Suryosubroto. Proses Belajar Mengajar Di Sekolah (Jakarta: Rineka Cipta. Tahun 2002), 287.

${ }^{3}$ Semula humanisme adalah gerakan dengan tujuan untuk mempromosikan harkat dan martabat manusia. Sebagai pemikiran etis yang menjunjung tinggi manusia. Humanisme menekankan harkat, peran, tanggugjawab menurut manusia. Menurut humanisme manusia mempuyai kedudukan yang istimewa dan berkemampuan lebih dari mahluk lainya karena mempunyai rohani. Pandangan humanisme membuat manusia sadar kembali tentang harkat dan martabat manusia sebagai mahluk rohani. Etika rohani mendasari manusia untuk bertangungjawab dalam kehidupan di dunia. Dalam pengunaan F.C.S Schiller dan William James, humanisme diangkat sebagai pandangan yang bertolak belakang dengan absolutisme filosofis. Ini tidak kembali kepandangan protagoras. Alasannya pandangan Schiller dan James dipandang melawan hal-hal absolut metafisis dan bukan yang epestimologis, yaitu melawan dunia tertutup idealisme absolut. Oleh karena itu, penekanannya pada alam atau dunia yang terbuka, pluralisme dan kebebasan manusia.
} 
suatu posisi Kristologis, yaitu kepercayaan bahwa Yesus Kristus adalah murni manusia. Kata itu pertama kali dipakai dalam konteks kebudayaan pada tahun $1832 .{ }^{4}$

Guru dalam konteks pendidikan humanistik diposisikan sebagai fasilitator bagi peserta didiknya. Peran guru dalam proses pembelajaran bukan lagi sebagai orang yang tahu segalanya tanpa melihat keseragaman potensi dan bakat yang sebenarnya dimiliki oleh peserta didik. Inilah yang menjadi ciri dari pendidikan humanistik, memandang manusia dengan positif sebagai satu kesatuan untuh yang punya potensi besar untuk dapat dikembangkan.

Kerangka dasar pemberian kegiatan ekstrakurikuler pendidikan agama Islam di Sekolah tetap mengacu kepada program pengajaran yang ada dalam kegiatan intrakurikuler. Oleh karena itu program kegiatan ekstrakurikuler merupakan bagian yang tidak terpisahkan dari program intrakurikuler.

\section{Pendekatan dan Metode penelitian}

1. Metode Penelitian

Metode yang dianggap cocok dalam penelitian ini adalah dengan menggunakan metode penelitian analisis deskriptif dengan pendekatan kualitatif, yaitu prosedur penelitian yang menghasilkan data deskriftif berupa kata-kata tertulis atau lisan dari orang-orang atau pelaku yang diamati kemudian di deskripsikan dan dianalisis. ${ }^{5}$ Penelitian deskriptif, peneliti lakukan untuk mengumpulkan informasi mengenai proses internalisasi nilai-nilai toleransi dalam upaya membina kerukunan umat beragama. Penelitian deskriptif dengan pendekatan kualitatif ini peneliti tidak dimaksudkan untuk menguji hipotesis tertentu melainkan hanya menggambarkan apa adanya hasil temuan, gejala atau keadaan yang peneliti temukan untuk kemudian disusun dan dituangkan dalam bentuk tulisan untuk diamati, ditafsirkan dan dianalisis dengan teori yang telah ada.

1. Sumber Data

a. Data Teoritik. Data teoritik adalah data yang diperoleh penulis berupa katakata dan tindakan orang-orang yang diamati melalui observasi dan wawancara. Observasi di sini ditunjukkan kepada kegiatan pengamatan atau

\footnotetext{
${ }^{4}$ Alister E. Mcgrath, Sejarah Pemikiran Reformasi, diterjemahkan oleh Liem Sien Kie (Jakarta: BPK Gunung Mulia, 2006), 53.

${ }^{5}$ Sugiyono, Memahami Penelitian Kualitatif (Alfabeta: Bandung, 2008), 122. 
pemuatan perhatian terhadap suatu objek yang akan diteliti dan kata-kata di sini diarahkan pada proses wawancara dengan fokus pada beberapa guru PAI, siswa dan civitas akademik lainnya.

b. Data Empirik. Data empirik ialah data yang diperoleh penulis setelah melakukan kajian teori dan pengamatan sebagai data penunjang. Misalnya, arsip-arsip, dokumen-dokumen, bukti otentik, wawancara dan lain-lain.

\section{Teknik Pengumpulan Data}

Untuk mengumpulkan berbagai data yang ada, maka peneliti menggunakan teknik-teknik pengumpulan data sebagai berikut:

a. Observasi. Metode Observasi ini peneliti menggunakan observasi pastisipatif, yaitu teknik pengumpulan data peneliti mengadakan pengamatan langsung terhadap gejalagejala subjek yang diselidiki. Menurut Sugiyono, teknik ini digunakan untuk mengamati secara langsung terhadap objek peneliti. ${ }^{6}$

b. Wawancara mendalam (indepth interview). Wawancara dilakukan dengan melakukan tanya jawab kepada narasumber yaitu Guru Pendidikan Agama Islam dan siswa.

c. Studi dukumentasi. Studi dokumentasi digunakan untuk mengumpulkan data yang berupa catatan-catatan, silabus pembelajaran, Rencana Pelaksanaan Pembelajaran (RPP), materi pelajaran dan lembar kerja peserta didik, format penilaian, tes, refleksi, jurnal, sekala sikap dan portofolio, laporan-laporan dan gambar-gambar kegiatan keagamaan, data-data peserta didik, dokumen-dokumen resmi secara tertulis yang memiliki relevansi dengan fokus penelitiandan dokumen-dokumen lain. Foto dan pengambilan video juga peneliti lakukan untuk memperkaya dokumen yang peneliti butuhkan. Baik itu foto dan video saat pembelajaran terjadi ataupun foto dan video yang mencerminkan gambaran perilaku kerukunan dan toleransi peserta didik di lingkungan sekolah.

\section{Teknik Analisis Data}

Setelah data terkumpul, selanjutnya adalah menganalisa data. Dalam menganalisis data dipergunakan analisis kualitatif deskriptif, yaitu proses analisis yang mendeskripsikan data

\footnotetext{
${ }^{6}$ Sugiyono, Metode Penelitian Pendidikan (Alfabeta: Bandung. 2005), 64. 
apa adanya dan menjelaskan data atau kejadian dengan kalimat-kalimat penjelasan secara kualitatif. $^{7}$

Adapun kegiatan analisis data meliput:

1. Reduksi Data. Data yang diperoleh telah diketik ulang dalam narasi. Data tersebut telah direduksi, dirangkum, dipilih hal pokok, difokuskan kepada hal yang penting dan berkaitan dengan masalah yang diteliti. Tujuannya, agar data yang direduksi memberikan gambaran mendalam/tajam tentang hasil pengamatan dan wawancara.

2. Display Data. Display data dilakukan apabila data yang terkumpul banyak, sehingga data terkumpul menimbilkan kesulitan dalam menggambarkan rincian keseluruhan pengambilan kesimpulan. Kesulitan memahami masalah ini diatasi dengan cara membuat model dan paradigma penelitian, sehingga keseluruhan data sebagai bagian dari rincian dipetakan secara jelas.

3. Kesimpulan dan Verifikasi. Menyimpulkan data berlangsung bertahap, dimulai dari kesimpulan umum kepada tahap reduksi data, kemudian menjadi lebih spesifik pada tahap penyajian data yang sudah dipolakan, difokuskan dan disusun secara sistematik, baik melalui penentuan tema maupun kesimpulan sehingga maksud dari data yang di dapat akan dimengerti. Verifikasi digunakan saat peneliti berhadapan dengan kasus yang dipandang negatif. Cara memperoleh hasil yang maksimal dapat dilihat dari tingkat akurasinya. Peneliti mencari kasus yang berbeda atau memperoleh hasil yang tingkat kepercayaannya lebih tinggi, mencakup situasi yang lebih luas, sehingga yang semula berlawanan akhirnya tidak lagi mengandung aspek yang tidak sesuai. $^{8}$

4. Uji Keabsahan Data. Uji kebasahan data adalah mengadakan pemeriksaan terhadap keabsahan data yang terkumpul. Hal ini dilakukan dengan didasarkan pada kriteria derajat kepercayaan, salinan, kebergantungan dan kepastian. Adapun cara yang ditempuh penulis dalam menguji keabsahan data adalah sebagai berikut:

a. Memperpanjang masa observasi, hal ini dimaksudkan untuk mendeteksi dan memperhitungkan distorsi yang mungkin merusak data. Distorsi bisa terjadi

\footnotetext{
${ }^{7}$ Sugiyono, Op. Cit. hal. 25.

${ }^{8}$ Lexy J Moleong, Metodologi Penelitian Kualitatif (Bandung : Remaja Rosdakarya, 1999), 122. 
karena unsur kesengajaan seperti bohong, menipu, dan berpura-pura oleh subyek, informan, key informan. Unsur kesengajaan dapat berupa kesalahan dalam mengajukan pertanyaan, motivasi, hanya untuk menyenangkan atau menyedihkan peneliti.

b. Pengamatan terus menerus. Dengan pengamatan terus menerus dan kontinyu, peneliti akan dapat memperhatikan sesuatu dengan lebih cermat, terinci dan mendalam. Pengamatan yang terus menerus, akhirnya akan dapat menemukan mana yang perlu diamati dan mana yang tidak perlu untuk diamati sejalan dengan usaha pemerolehan data. Pengamatan secara terus menerus dilakukan untuk dapat menjawab pertanyaan penelitian tentang fokus yang diajukan.

c. Trianggulasi data. Tujuan trianggulasi data dilakukan dalam penelitian ini adalah untuk mengecek kebenaran data dengan membandingkan data yang diperoleh dari sumber lain, pada berbagai fase penelitian di lapangan. Trianggulasi data yang dilakukan dalam penelitian ini adalah dengan sumber dan metode, artinya peneliti membandingkan dan mengecek balik derajat kepercayaan informasi yang diperoleh melalui waktu dan alat yang berbeda dalam metode kualitatif. Trianggulasi data dengan sumber ini antara lain dilakukan dengan cara membandingkan data yang diperoleh dari hasil wawancara dengan informan dan key informan. Trianggulasi data dilakukan dengan cara, pertama, membandingkan hasil pengamatan pertama dengan pengamatan berikutnya. Kedua, membandingkan data hasil pengamatan dengan hasil wawancara. Membandingkan data hasil wawancara pertama dengan hasil wawancara berikutnya. Penekanan dari hasil perbandingan ini bukan masalah kesamaan pendapat, pandangan, pikiran semata-mata. Tetapi lebih penting lagi adalah bisa mengetahui alasan-alasan terjadinya perbedaan.

d. Membicarakan dengan orang lain (peer debriefing), mendiskusikan hasil data dengan orang lain yang paham dengan penelitian yang sedang dilakukan.

e. Menganalisis kasus negatif, yang bermaksud mencari kebenaran dari suatu data yang dikatakan benar oleh suatu sumber data tetapi ditolak oleh sumber yang lainnya. 
f. Menggunakan bahan referensi sebagai pembanding dan untuk mempertajam analisa data.

g. Mengadakan member check. Tujuan mengadakan member check adalah agar informasi yang telah diperoleh dan yang akan digunakan dalam penulisan laporan dapat sesuai dengan apa yang dimaksud oleh informan, dan key informan. Untuk itu dalam penelitian ini member check dilakukan setiap akhir wawancara dengan cara mengulangi secara garis besar jawaban atau pandangan sebagai data berdasarkan catatan peneliti tentang apa yang telah dikatakan oleh responden. Tujuan ini dilakukan adalah agar responden dapat memperbaiki apa yang tidak sesuai menurut mereka, mengurangi atau menambahkan apa yang masih kurang. Member check dalam penelitian ini dilakukan selama penelitian berlangsung sewaktu wawancara secara formal maupun informal berjalan.

\section{Kegiatan Ekstra Kurikuler di Sekolah}

\section{Pengertian Kegiatan Ekstra Kurikuler}

Menurut Peraturan Menteri Pendidikan Dan Kebudayaan Republik Indonesia Lampiran III Nomor 81a tahun 2013 Tentang Implementasi Kurikulum menyebutkan bahwa Pengembangan potensi peserta didik sebagaimana dimaksud dalam tujuan pendidikan nasional tersebut dapat diwujudkan melalui kegiatan ekstrakurikuler yang merupakan salah satu kegiatan dalam program kurikuler. ${ }^{9}$ Kegiatan ekstrakurikuler adalah program kurikuler yang alokasi waktunya tidak ditetapkan dalam kurikulum. Jelasnya bahwa kegiatan ekstrakurikuler merupakan perangkat operasional (supplement dan complements) kurikulum, yang perlu disusun dan dituangkan dalam rencana kerja tahunan/kalender pendidikan satuan pendidikan. Kegiatan ekstrakurikuler menjembatani kebutuhan perkembangan peserta didik yang berbeda; seperti perbedaan sensitifitas terhadap nilai moral dan sikap, kemampuan, dan kreativitas. Melalui partisipasinya dalam kegiatan ekstrakurikuler peserta didik dapat belajar dan mengembangkan kemampuan berkomunikasi, bekerja sama dengan orang lain, serta menemukan dan mengembangkan potensinya juga memberikan manfaat sosial yang besar.

\footnotetext{
${ }^{9}$ Kementerian dan Pendidikan dan Kebudayaan, Lampiran Permendikbud Nomor 81A Tahun 2013 Tentang Implementasi Kurikulum Pedoman Umum Pembelajaran (Jakarta: Kementerian Pendidikan dan Kebudayaan RI. 2013), 11.
} 
Lampiran III Peraturan Menteri Pendidikan dan Kebudayaan No.81a tahun 2013 tentang Implementasi Pendidikan juga menjelaskan bahwa, ekstrakurikuler adalah kegiatan pendidikan yang dilakukan oleh peserta didik diluar jam belajar kurikulum standar sebagai perluasan dari kegiatan kurikulum dan dilakukan dibawah bimbingan sekolah dengan tujuan untuk mengembangkan kepribadian, bakat, minat, dan kemampuan peserta didik yang lebih luas atau diluar minat yang dikembangkan oleh kurikulum. Berdasarkan definisi tersebut, maka kegiatan di sekolah atau pun di luar sekolah yang terkait dengan tugas belajar suatu mata pelajaran bukanlah kegiatan ekstrakurikuler. Ekstrakurikuler wajib merupakan program ekstrakurikuler yang harus diikuti oleh seluruh peserta didik, terkecuali bagi peserta didik dengan kondisi tertentu yang tidak memungkinkannya untuk mengikuti kegiatan ekstrakurikuler tersebut. Ekstrakurikuler pilihan merupakan program ekstrakurikuler yang dapat diikuti oleh peserta didik sesuai dengan bakat dan minatnya masing-masing. Jadi dapat disimpulkan bahwa kegiatan ekstrakulikuler adalah kegiatan diluar jam pelajaran yang bisa dilakukan di sekolah maupun di luar sekolah pada waktu yang ditentukan oleh pihak sekolah yang tujuannya adalah guna menambah wawasan dan pengetahuan serta menanamkan nilainilai dan sikap yang baik bagi siswa.

2. Pelaksanaan dan Peranan Kegiatan Ekstrakurikuler di Sekolah

Visi kegiatan ekstra kurikuler adalah berkembangnya potensi, bakat dan minat potensi, bakat dan minat secara optimal serta tumbuhnya kemandirian dan kreatfitas peserta didik yang berguna untuk diri sendiri, keluarga dan masyarakat. Misi kegiatan ekstra kurikuler yaitu berupa : pertama; menyediakan sejumlah kegiatan yang menyediakan sejumlah kegiatan yang dapat dipilih oleh peserta didik sesuai dengan kebutuhan, potensi, bakat dan minat mereka. Kedua; menyelenggarakan kegiatan yang memberikan kesempatan peserta didik mengekspresikan diri secara bebas melalui kegiatan mandiri dan atau kelompok.

Kegiatan ekstrakurikuler merupakan kegiatan belajar yang dilakukan di luar jam pelajaran atau jam tatap muka dengan maksud memberikan pengayaan atau menambah materi yang telah ada dalam jam intrakurikuer. Kegiatan ekstrakurikuler dapat dilaksanakan di sekolah atau di luar sekolah untuk lebih memperluas wawasan atau kemampuan, peningkatan atau penerapan nilai pengetahuan yang telah dipelajari dalam jam pelajaran. 
Kegiatan ekstra kurikuler merupakan kegiatan penunjang intra kurikuler untuk mengembangkan minat dalam menumbuh kembangkan pribadi peserta didik yang sehat jasmani dan rohani, bertaqwa kepada Tuhan Yang Maha Esa, memiliki kepedulian dan bertanggung jawab melalui berbagai kegiatan positif dibawah kewenangan sekolah.

Tantangan pendidikan pada abad serba modern seperti sekarang ini Nampak terasa semakin berat. Kemajuan ilmu peng dan tekhnologi dengan segala pengaruhnya tidak dapat dihindari. Perubahan-perubahan sosial budaya, etika dan tata nilai moral akibat asimilasi kebudayaan dari luar yang dibawa atau diperoleh melalui jasa tekhnologi merupakan ancaman yang senantiasa harus diwaspadai. Itulah sebabnya Pendidikan Agama Islam (PAI) merupakan benteng untuk senantiasa mampu memberikan kepribadian secaraa utuh.

Dalam pelaksanaan pendidikan secara islami, pendidikan agama di sekolah di rasakan kurang sangat terbatas waktu pembelajarannya, sehingga perlu strategi untuk mencari cara yang tepat guna menghindari prasangka peserta didik yang merasa terpaksa dan dengan cara atau contoh moral yang baik dalam kehidupan sehari-hari di lingkungan masyarakat. Pendidikan secara islami yang diselenggarakan dalam kegiatan ekstra kurikuler mempunyai peranan yang sangat penting dan dibutuhkan pada saat dunia semakin maju.

Menurut Zakiyah Daradjat menjelaskan bahwa pendidikan moral masyarakat harus diupayakan dengan cara usaha sebagai berikut :

a. Supaya buku, gambar, tulis, bacaan yang akan membawa kerusakan moral anak perlu dilarang peredarannya. Semua ini akan merusak mental dan moral anak, sekaligus akan menghancurkan hari depan bangsa kita

b. Supaya dihindari segala kemungkinan terjadinya tindakan atau perbuatan yang bertentangan dengan ajaran agama Islam dalam pergaulan anak terutama di tempat rekreasi dan olah raga.

c. Supaya segala media massa, terutama sarana radio dan televise memperhatikan setiap macam uraian pertunjukkan, kesenian dan ungkapan, jangan sampai ada yang bertentangan dengan ajaran agama dan membawa kemerosotan moral.

d. Supaya permainan dan tempat yang dapat mengganggu ketentraman batin anak ramaja dilarang. 
e. Supaya pertentangan golongan dalam masyarakat dikurangi, kalau tidak dapat dibendung sama sekali, karena pertentangan tersebut akan menyebabkan kegelisahan dan kegoncangan batin yang akan memudahkan terpengaruhnya mereka oleh suasana luar. ${ }^{10}$

Alokasi waktu kegiatan intrakurikuler pendidikan agama Islam di Sekolah dirasakan kurang seimbang dengan bobot materi pelajaran yang harus diberikan. Jumlah jam pelajaran yang dialokasikan dalam struktur program pengajaran dirasakan sangat kurang. Oleh karena itu salah satu alternatif untuk mengatasi kekurangan waktu yang tersedia kegiatan ekstrakurikuler menjadi alternatif pemecahan.

Untuk memberikan kegiatan ekstrakurikuler pendidikan agama Islam, setiap guru pendidikan agama Islam hendaknya memahami bahwa eksistensi kegiatan ekstrakurikuler merupakan bagian dari kegiatan intrakurikuler yang harus dilaksanakan dengan sebaikbaiknya. Pelaksanaan kegiatan ekstrakurikuler tentunya berbeda dengan kegiatan intrakurikuler. Program ekstrakurikuler harus lebih menarik, sehingga siswa tidak merasa jemu dan bosan untuk mengikutinya. Oleh karena itu program kegiatan ekstrakurikuler harus menekankan pendekatan praktis. Artinya kegiatan ekstrakurikuler harus lebih banyak melakukan kegiatan praktek dan lebih bersifat aplikatif.

\section{E. Kegiatan Ekstra Kurikuler Keagamaan Islam}

Dalam Keputusan Menteri Pendidikan Nasional RI Nomor 125/U/2002 tentang Kalender Pendidikan dan Jam Belajar Efektif di Sekolah, Bab V pasal 9 ayat 2, dinyatakan bahwa:

Pada tengah semester 1 dan 2 sekolah melakukan kegiatan olahraga seni (Porseni), karyawisata, lomba kreativitas atau praktik pembelajaran yang bertujuan untuk mengembangkan bakat kepribadian, prestasi dan krativitas siswa dalam rangka mengembangkan pendidikan anak seutuhnya. ${ }^{11}$

Pada bagian Lampiran Keputusan Mendiknas Nomor 125 / U / 2002 tanggal 31 Juli 2002 disebutkan:

\footnotetext{
${ }^{10}$ Zakiyah Daradjat, Membina Nilai-nilai Moral di Indonesia (Jakarta: Bulan Bintang, 1968), 23.

${ }^{11}$ Himpunan Keputusan Menteri Pendidikan Nasional RI (Jakarta: Sinar Grafika, 2007), Cet. 2. 
Liburan sekolah atau madrasah selama bulan Ramadhan diisi dan dimanfaatkan untuk melaksanakan berbagai kegiatan yang diarahkan pada peningkatan akhlak mulia, pemahaman, pendalaman dan amaliah agama termasuk kegiatan ekstrakurikuler lainnya yang bermuatan moral.

Sesuai dengan prinsip kegiatan ekstrakurikuler bahwa program ekstrakurikuler merupakan penunjang kegiatan intrakurikuler, maka setiap program ekstrakurikuler, harus memperhatikan bentuk-bentuk pengayaan apa yang di mungkinkan dapat dilaksanakan dalam kegiatan ekstra kurikuler.

Untuk dapat menyusun program kegiatan ekstrakurikuler yang baik diperlukan adanya beberapa langkah kegiatan yang harus diperhatikan, antara lain:

1. Menyusun program pengajaran (intrakurikuler) secara baik untuk tiap semester.

2. Menginventarisir materi-materi pendidikan agama Islam yang memungkinkan dapat dilaksanakan pengayaannya dalam kegiatan ekstra kurikuler.

3. Memperhitungkan daya dukung dan kemungkinan sarana yang diperlukan dan dapat memperlancar pelaksanaan kegiatan ekstrakurikuler.

4. Memperhitungkan kemungkinan potensi tenaga pengajar yang dapat membantu pelaksanaan kegiatan ekstrakurikuler.

5. Siswa yang dapat mengikuti kegiatan ekstrakurikuler, misalnya untuk kelas I dan II belum diikutsertakan karena masih belum memungkinkan untuk dapat mengikutinya. Pertimbangan tersebut di atas merupakan langkah awal guru pendidikan agama Islam dalam menyusun program kegiatan ekstrakurikuler. Pertimbangan-pertimbangan itu dirasakan sangat penting untuk melihat kemungkina apakah suatu materi pokok bahasan yang dapat diberikan kegiatan pengayaan dalam bentuk kegiatan ekstrakurikuler.

Banyak jenis dan bentuk kegiatan ekstrakurikuler keagamaan yang dilaksanakan, antara lain:

1. Peraktek Ibadah, yang meliputi:

\section{a. Thoharah}

kegiatan thoharah atau bersuci yang dapat dilaksanakan dalam kegiatan ekstrakurikuler yaitu cara berwudhu dan bertayamum. Kegiatan ekstrakurikuler 
kegiatan thoharah dimaksudkan untuk memperdalam sajian bahan pelajaran yang diberikan dalam jam intrakurikuler, karena dimungkinkan terbatasnya waktu yang tersedia penyajian materi tentang thoharah tidak dapat dilakukan secara maksimal.

Kegiatan thoharah merupakan salah satu kegiatan yang selalu ditemukan dan dilaksanakan dalam kehidupan sehari-hari. Oleh karena itu pemberian ekstrakurikuler bagi materi pendidikan agama mengenai thoharah sangatlah penting agar siswa lebih dalam penguasaannya.

Pelaksanaan kegiatan ekstra kurikuler dapat dilakukan secara integral, artinya untuk beberapa hal dapat dilakukan dalam satu kegiatan, seperti cara berwudhu dan tayamum dapat disatukan dengan kegiatan shalat.

b. Shalat

Kegiatan shalat dilakukan untuk memperdalam dan menguatkan penguasaan pengetahuan siswa mengenai cara melakukan shalat, baik shalat berjamaah maupun shalat munfarid.

Pendidikan agama Islam dalam orientasi dan pendekatannya lebih menanamkan pada penanaman kebiasaan sehingga pemberian materi pelajaran harus lebih menekankan pada penanaman kebiasaan. Itulah sebabnya pelaksanaan kegiatan ekstrakurikuler cara shalat dimaksudkan untuk menumbuhkan kebiasaan yang harus dimiliki siswa dalam mengaplikasikan pendidikan agama dalam kehidupan sehari-hari secara kognitif siswa mengenal beberapa pengetahuan mengenai shalat (macammacam shalat sunah) yang kemudian diaplikasikan dan dipraktekkan dalam kehidupan sehari-hari.

c. Shalat Jum'at

Shalat Jum'at merupakan salah satu bentuk kegiatan ekstrakurikuler yang diwajibkan untuk siswa laki-laki. Hal ini dilakukan dengan cara praktek perbuatan untuk mengenal secara lebih mendalam tentang pelaksanaan shalat Jum'at. Kegiatan ekstrakurikuler dalam bentuk shalat Jum'at untuk membimbing agar siswa lebih memahami dan menghayati ibadah shalat yang dilakukan pada waktu hari Jum'at. 


\section{Baca Tulis Al-Qur'an (BTQ)}

Pelaksanaan baca tulis Al-Qur'an secara intensif dapat dilaksanakan di luar jam pelajaran. Baca tulis Al-Qur'an dapat dilakukan dalam bentuk menghafal ayat dan surat-surat pendek. Kegiatan ekstrakurikuler dalam bentuk baca tulis Al-Qur'an sangat bermanfaat untuk bekal mempelajari pendidikan agama secara lebih mendalam 3. Khitobah

Khitobah merupakan kegiatan ekstrakurikuler yang senantiasa dilakukan oleh seluruh siswa yaitu siswa kelas VII sampai IX. Teknik pelaksanaannya pun terbatas hanya pada saat sebelum dilaksanakan upacara bendera hari senin. Hal ini dimaksudkan untuk menanamkan mental kepada peserta didik dan melatih berbicara didepan publik. Bahan-bahan materi yang disampaikan sebagai penguatan dari materi pelajaran yang telah disampaikan pada kegiatan ekstra kurikuler.

\section{F. Pola Pendidikan Humanis}

\section{Pengertian Pendidikan Humanis}

Teori-teori belajar sejauh ini telah menekankan peranan lingkungan dan faktor-faktor kognitif dalam proses belajar mengajar. Teori humanistik secara jelas menunjukkan bahwa belajar dipengaruhi oleh bagaimana siswa-siswa berpikir dan bertindak, dan dipengaruhi dan diarahkan oleh arti pribadi dan perasaan-perasaan yang mereka ambil dari pengalaman belajar mereka.

Menurut Sri Esti. W Djiwandono, ahli-ahli teori humanistik menunjukkan bahwa 1) tingkah laku individu pada mulanya ditentukan oleh bagaimana mereka merasakan dirinya sendiri dan dunia sekitarnya, dan 2) individu bukanlah satu-satunya hasil dari lingkungan mereka seperti yang dikatakan oleh teori ahli tingkah laku, melainkan langsung dari dalam (internal), bebas memilih, dimotivasi oleh keinginan untuk aktualisasi diri (self actualization) atau memenuhi potensi keunikan mereka sebagai manusia. ${ }^{12}$

Humanisme lebih melihat pada sisi perkembangan kepribadian manusia. Pendekatan ini melihat kejadian yaitu bagaimana manusia membangun dirinya untuk melakukan hal-hal yang positif. Kemampuan bertindak positif ini yang disebut sebagai potensi manusia dan para

\footnotetext{
${ }^{12}$ Sri Esti Wuryani Djiwandono, Psikologi Pendidikan (Jakarta: PT. Grasindo, 2002), 181. 


\section{Al-Tarbawi Al-Haditsah: Jurnal Pendidikan Islam}

Vol. 3, No. 2, Desember 2018

pendidik yang beraliran humanisme biasanya memfokuskan pengajarannya pada pembangunan kemampuan positif ini. Kemampuan positif disini erat kaitannya dengan pengembangan emosi positif yang terdapat dalam domain afektif, emosi adalah karakterisitik yang sangat kuat yang nampak dari para pendidik beraliran humanisme.

Dari perspektif humanistik, pendidik seharusnya memperhatikan pendidikan yang lebih responsif terhadap kebutuhan kasih sayang (affective) siswa. Kebutuhan afektif adalah kebutuhan yang berhubungan dengan emosi, perasaan, nilai, sikap, predisposisi dan moral.

Humanisme dalam kajian psikologi merupakan aliran yang tergolong baru. Banyak ahli menyebutkan bahwa, aliran ini muncul sebagai bentuk kekecewaan dari teori-teori psikologi sebelumnya, dalam hal ini teori behavioristik dan psikoanalistik. Dalam perkembangan awalnya, aliran psikologi humanisme hanya terbatas pada kajian tentang kepribadian manusia. Akan tetapi, sejalan dengan perkembangan ilmu pengetahuan, teori ini telah banyak dikembangkan oleh beberapa pakar pendidikan untuk di implementasikan dalam dunia pendidikan. Dan salah satu pendekatan yang dikembangkan melalui teori humanisme ini adalah pendekatan Quantum Learning. Pendekatan pembelajaran ini dalam pelaksanaannya dinilai terdapat unsur humanismenya. Yaitu memberikan kesempatan kepada siswa untuk mengeksplorasi kemampuan, bakat, dan potensinya dalam pembelajaran. Dalam hal ini, guru hanya berperan sebagai fasilitator.

Telah disinggung di awal bahwa teori humanistik muncul dikarenakan risih dengan anggapan teori-teori sebelumnya, psikoanalisis dan behavioristik yang menganggap seolaholah manusia tidak berdaya dengan dirinya sendiri yang kepribadiannya selalu dipengaruhi oleh lingkungan. Isu dehumanisasi juga menjadi perhatian kaum humanisme dalam menyusun teorinya. Humanisme muncul dengan misi untuk menempatkan dan memandang manusia sebagai mahluk yang unik dengan berbagai potensi yang ada dalam dirinya.

Humanisme yakin bahwa manusia dalam dirinya memiliki potensi untuk berkembang sehat dan kreatif, dan jika orang mau menerima tanggung jawab dalam hidupnya sendiri, dia akan menyadari potensinya, mengatasi pengaruh kuat dari pendidikan orang tua, sekolah, dan tekanan sosial lainnya.

Selanjutnya pandangan humanisme dalam kepribadian menekankan dalam hal-hal berikut: 
a. Holisme

Menegaskan bahwa organisme selalu bertingkah laku sebagai kesatuan yang utuh, bukan rangkaian bagian/komponen yang berbeda.

b. Menolak riset binatang

Psikologi humanistik menekankan perbedaan antara tingkah laku manusia dengan tingkah laku binatang. Riset binatang memandang manusia sebagai mesin dan mata rantai refleks - conditioning, mengabaikan karakteristik manusia yang unik seperti ide, nilai-nilai, keberanian, cinta, humor, cemburu, dosa, puisi, musik, ilmu, dan hasil kerja berfikir fisik lainnya. Hal inilah yang menurut Maslow teori behavioristik secara filosofis berpandangan dehumanisme.

c. Potensi kreatif

Kreativitas merupakan ciri universal manusia sejak dilahirkan. Kreativitas adalah potensi semua orang, yang tidak memerlukan bakat dan kemampuan khusus. Umumnya justru orang kehilangan kreativitas ini karena proses pembudayaan .

d. Menekankan kesehatan psikologis

Humanistik mengarahkan pusat perhatiannya kepada manusia sehat, kreatif, dan mampu mengaktualisasikan diri. Psikologi humanistik atau disebut juga dengan nama psikologi kemanusiaan adalah suatu pendekatan yang multifaset terhadap pengalaman dan tingkah laku manusia, yang memusatkan perhatian pada keunikan dan aktualisasi diri manusia. Bagi sejumlah ahli psikologi humanistik ia adalah alternatif, sedangkan bagi sejumlah ahli psikologi humanistik yang lainnya merupakan pelengkap bagi penekanan tradisional behaviorisme dan psikoanalis.

Psikologi humanistik dapat dimengerti dari tiga ciri utama, yaitu, pertama psikologi humanistik menawarkan satu nilai yang baru sebagai pendekatan untuk memahami sifat dan keadaan manusia. Kedua, ia menawarkan pengetahuan yang luas akan kaedah penyelidikan dalam bidang tingkah laku manusia. Ketiga, ia menawarkan metode yang lebih luas akan kaedah-kaedah yang lebih efektif dalam pelaksanaan psikoterapi. Pokok persoalan dari psikologi humanistik adalah pengalaman subjektif manusia, keunikannya yang membedakan dari hewan-hewan, sedangkan area-area minat dan penelitian yang utama dari psikologi humanistik adalah kepribadian yang 
normal dan sehat, motivasi, kre ativitas, kemungkinan-kemungkinan manusia untuk tumbuh dan bagaimana bisa mencapainya, serta nilai-nilai manusia. Dalam metodemetode studinya, psikologi humanistik menggunakan berbagai metode mencakup wawancara, sejarah hidup, sastra, dan produk-produk kreatif lainnya.

Dari uraian diatas dapat ditarik kesimpulan bahwa teori humanistik memandang, 1) manusia sebagai mahluk sempurna yang memiliki potensi besar untuk dapat survive menjalani kehidupannya, 2) dengan dimilikinya potensi yang besar itulah yang membedakan manusia dengan hewan, dan dengan potensi tersebut manusia dapat mengendalikan dirinya dan lingkungannya, bukan sebaliknya.

2. Membentuk Lingkungan Pendidikan Humanis

Dalam konteks pendidikan, pendekatan humanisme dewasa ini semakin banyak digagas oleh beberapa pakar sebagai pendidikan alternatif. Maraknya praktik-praktik dehumanisasi dalam pendidikan menjadikan pendekatan humanisme ini banyak diadopsi kedalam dunia pendidikan, baik secara paradigma maupun aplikasinya. Pendidikan saat ini tidak lagi menganggap peserta didik sebagai objek, akan tetapi sebaliknya. Pelaksanaan pendidikan sudah saatnyalah memfokuskan pada optimalisasi potensi yang dimiliki peserta didik.

Salah satu model pendidikan terbuka mencakup konsep belajar guru yang fasilitatif yang dikembangkan oleh Rogers ${ }^{13}$ (pakar teori humanistik) yang diteliti oleh Aspy dan Roebuck pada tahun 1975 mengenai kemampuan para guru untuk menciptakan kondisi yang mendukung yaitu empati, penghargaan, dan umpan balik positif. Dalam mengaplikasikan pendekatan pembelajaran yang humanistik, dalam hal ini guru yang berperan sebagai fasilitator mempunyai beberapa ciri-ciri sebagai berikut :

a. Merespon perasaan siswa

\footnotetext{
${ }^{13}$ Carl Ransom Rogers dilahirkan di Oak Park, Illinois, pada tahun 1902 dan wafat di LaJolla, California, pada tahun 1987. Rogers adalah putra keempat dari enam bersaudara. Rogers dibesarkan dalam keluarga yang berkecukupan dan menganut aliran protestan fundamentalis yang terkenal keras, dan kaku dalam hal agama, moral dan etika. Rogers merupakan salah satu pakar psikologi humanistik yang terkenal. la berjasa besar dalam mengantarkan psikologi humanistik untuk dapat diaplikasian dalam pendidikan. Dia mengembangkan satu filosofi pendidikan yang menekankan pentingnya pembentukan pemaknaan personal selama berlangsungnya proses pembelajaran dengan melalui upaya menciptakan iklim emosional yang kondusif agar dapat membentuk pemaknaan personal tersebut. Dia memfokuskan pada hubungan emosional antara guru dengan siswa.
} 
b. Menggunakan ide-ide siswa untuk melaksanakan interaksi yang sudah dirancang

c. Berdialog dan berdiskusi dengan siswa

d. Menghargai siswa

e. Kesesuaian antara perilaku dan perbuatan

f. Menyesuaikan isi kerangka berfikir siswa (penjelasan untuk menetapkan kebutuhan segera dari siswa)

g. Tersenyum pada siswa

Guru yang fasilitatif mengurangi angka bolos siswa, meningkatkan angka konsep diri siswa, meningkatkan upaya untuk meraih prestasi akademik termasuk pelajaran bahasa dan matematika yang kurang disukai, mengurangi tingkat problem yang berkaitan dengan disiplin dan mengurangi perusakan pada peralatan sekolah, serta siswa menjadi lebih spontan dan menggunakan tingkat berfikir lebih tinggi.

Dalam perspektif humanisme, proses pembelajaran bukan pada bagaimana "mengajarkan", akan tetapi lebih pada bagaimana "menciptakan situasi belajar" yang akan membuat peserta didik mengalami pengalaman belajar itu sendiri. Dengan pendekatan seperti ini, akan memungkinkan bagi peserta didik paham akan makna belajar, inilah sesungguhnya hakikat dari pendidikan yang humanis.

Rogers, salah satu pakar psikologi humanistik mengungkapkan tentang belajar dengan mengetahui terlebih dahulu maka dari belajar itu sendiri, yang dikenal dengan belajar penuh arti yaitu, sikap murni, apa adanya, penghargaan, penerimaan, kepercayaan, dan pemahaman dengan empati. ${ }^{14}$ Proses internalisasi nilai sopan santun dalam lingkungan pendidikan humanis.

\section{G. Kesimpulan}

Untuk mewujudkan lingkungan pendidikan yang humanis salah satunya dilakukan kegiatan ekstra kurikuler yang dilaksanakan oleh para siswa secara antusias dan penuh semangat. Terkhusus kegiatan ekstra kurikuler keagamaan dilakukan secara rutin dan terjadwal, menjadikan para siswa lebih mengetahui tentang ilmu keagamaan, sehingga ajaran-

\footnotetext{
${ }^{14}$ Carl Rogers, Freedom To Learn, (Columbus, Ohio: Merrill, 1969), dalam C.H. Patterson, Foundation for a Theory of Instructional and Educational Psychology, (Harper\&Row, 1977) 
ajaran keagamaan bisa dipraktekan secara langsung baik dilingkungan sekolah ataupun di rumah. Misalnya para siswa dipesankan untuk senantiasa menghormati para guru, menghargai teman sekolah dan menyayangi kedua orang tua dirumah. Berikutnya para siswa dibiasakan untuk bersikap sopan santun kepada para guru, sesama teman dilingkungan sekolah dan bersikap sopan santun kepada kedua orang tua sewaktu dirumah.

\section{DAFTAR PUSTAKA}

Daradjat, Zakiyah, Membina Nilai-nilai Moral di Indonesia. Jakarta: Bulan Bintang, 1968.

Djiwandono, Sri Esti Wuryani, Psikologi Pendidikan, Jakarta: PT. Grasindo, 2002.

Himpunan Keputusan Menteri Pendidikan Nasional RI, Jakarta: Sinar Grafika, 2007, Cet. 2.

Kementerian dan Pendidikan dan Kebudayaan, Lampiran Permendikbud Nomor 81A Tahun 2013 Tentang Implementasi Kurikulum Pedoman Umum Pembelajaran, Jakarta: Kementerian Pendidikan dan Kebudayaan RI. 2013.

Moleong, Lexy, J Metodologi Penelitian Kualitatif, Bandung : Remaja Rosdakarya, 1999.

Mcgrath, Alister E., Sejarah Pemikiran Reformasi, diterjemahkan oleh Liem Sien Kie, Jakarta: BPK Gunung Mulia, 2006.

Patterson, C.H., Foundation for a Theory of Instructional and Educational Psychology, Harper\&Row, 1977.

Rogers, Carl, Freedom To Learn, Columbus, Ohio: Merrill, 1969.

Sugiyono, Memahami Penelitian Kualitatif. Alfabeta: Bandung, 2008.

Sugiyono, Metode Penelitian Pendidikan, Alfabeta: Bandung. 2005.

Suryosubroto, Proses Belajar Mengajar Di Sekolah, Jakarta: Rineka Cipta. Tahun 2002.

Tim Penyusun Pusat Kamus, Kamus Besar Bahasa Indonesia, Jakarta: Balai Pustaka, Edisi-3, tahun 2007. 